\title{
Role of gut-lung microbiome crosstalk in COVID-19
}

\author{
B. S. Srinath ${ }^{1} \cdot$ Rajesh P. Shastry $^{2}$ (D) Sukesh B. Kumar ${ }^{2}$
}

Received: 15 June 2020 / Accepted: 17 November 2020 / Published online: 24 November 2020

(C) Sociedade Brasileira de Engenharia Biomedica 2020

\begin{abstract}
Purpose Gut microbiota are able to generate metabolites that can alter the function of immune cells and play a major role in health and disease. Understanding the changes in gut microbiome during infections including virus may help to use novel strategies in the therapeutic interventions.

Methods We have reviewed recent reports on role of gut microbiome in lung infections and its possible importance in COVID-19. Results Most of the studies provide an insight into the possible role of gut microbes during lung diseases including chronic obstructive pulmonary disease (COPD), cystic fibrosis, lung cancer, and other respiratory problems such as allergy and asthma. However, clinical evidence underlying gut-lung crosstalk during respiratory viral infections is limited.

Conclusion This review provides an overview of the role of the gut microbiome during respiratory viral infections mainly focused on COVID-19 and possible evidence for its crosstalk targeting as new therapeutics.
\end{abstract}

Keywords Respiratory viral infections $\cdot$ Microbiome $\cdot$ COVID-19 $\cdot$ Gut-lung axis

\section{Introduction}

In December 2019, a series of cases of unsolved respiratory viral pneumonia was occurred in Wuhan, China. Primarily, most of the cases were considered to have linked with the seafood market in Wuhan. Later, it was identified that human to human transmission played a major role in the disease outbreak (Yuki et al. 2020). This disease was rapidly spread from Wuhan to other places in China and the rest of the world. To identify the causal organism of this disease, a huge number of tests were conducted. Finally, the International Committee on Taxonomy of Viruses (ICTV) named the causative virus as SARS-CoV-2 and the disease name as COVID-19 (Cui et al. 2019). This disease has been affecting a huge number of people in the worldwide, approximately more than 216 countries

B. S. Srinath and Rajesh P. Shastry contributed equally to this work.

Rajesh P. Shastry

rpshastry@gmail.com; rpshastry@yenepoya.edu.in

1 Department of Studies and Research in Microbiology, Post Graduate Centre, Mangalore University, Jnana Kavery Campus, Kodagu, Karnataka 571232, India

2 Division of Microbiology and Biotechnology, Yenepoya Research Centre, Yenepoya (Deemed to be University), University Road, Deralakatte, Mangalore 575018, India and territories (Zhang et al. 2020c; Zheng 2020). As of 21st October 2020, around 40,251,950 cases have been infected and $1,116,131$ deaths occurred worldwide according to the World Health Organization (WHO, 2020).

Six species of corona viruses are well known to cause diseases in human, among them the Middle East Respiratory syndrome Coronavirus (MERS-CoV) and Severe Acute Respiratory Syndrome Coronavirus (SARS-CoV) are zoonotic diseases, which caused severe respiratory illness and had higher fatality rates (Ye et al. 2020). Now, the recent pandemic COVID-19 is the seventh type of corona viruses. Phylogenetic study of its single stranded RNA viral genome $(29,903$ nucleotides) has revealed that the COVID-19 is almost similar (89.1\% nucleotide) with SARS-like coronaviruses that had previously found in bats in China (Wu et al. 2020b). This information possibly explains the behavior of the present novel COVID-19 in human infection. Moreover, the mutational profile shows the highest mutation in the orflab gene especially the transitional mutation is much more frequent than transversion (Gupta et al. 2020). SARS-CoV-2 multifractal approach-based study concluded that structure organization linked to large fluctuations in genome imparting virulence in the virus (Mandal et al. 2020). Now, the current trend is the development of an effective vaccine and clinically efficient therapeutic treatment methods for COVID-19. Until that, we are reliant on preventative methods, such as social distancing and good hand hygiene to minimize the infection rates (WHO, 2020). An alternative addition to 
such preventative measures would be the strengthening immune system of individuals to better fight against COVID-19 (Gasmi et al. 2020). Here, our normal gut microbiome comes to play a significant role. We know that trillions of nonpathogenic bacteria are living within our gut system referred as gut microbiome or normal microbiota. These organisms perform important functions in the body such as the production of vitamins, aiding digestion, and stimulation of our immune system to fight against infectious pathogens (Lazar et al. 2018). Maintaining a high level of gut bacterial diversity is key to maintain good health. A loss of bacterial diversity in the gut results in a physiological change within our gut system that can initiate common infections and inflammation. It is also common that the microbiome of the gut can decrease with the age, this may also be important factors in COVID-19 infections and high mortality rate in older aged people (Gasmi et al. 2020).

So far, many researchers (Liu et al. 2020; Chen et al. 2020b; Huang et al. 2020) have been focused on the clinical symptoms of the COVID-19 patients; the obtained results revealed that those individuals are older or having other clinical complications are more susceptible to COVID-19 infection. Many people, particularly the younger, are less susceptible and develop only very mild disease. Recent researchers have confirmed that the gut microbiota plays an important role in the body defense mechanism and mounting an immune response to pathogens like coronavirus (Chen et al. 2020b; Huang et al. 2020). Previous reports confirmed that coronavirus enters into human cells by binding with angiotensin converting enzyme 2 (ACE2) receptor. ACE2 is necessary for entry of SARS-CoV-2 through viral spike (S) proteins and involvement of host cellular serine protease TMPRSS2 as a cofactor for S protein priming (Yan et al. 2020). A recent study observed that natural variations facilitate a higher expression of ACE2 depending on the population and functional gene expression. This result in ACE2 homo-dimerization, which leads to hindrance of TMPRSS2 mediated cleavage of ACE2 and reduced or no SARS-CoV-2 entry or viral replication (Sharma et al. 2020).

ACE2 also has the main impact on gut microbiota composition, consequently affecting cardiopulmonary infections (ColeJeffrey et al. 2015). Over 60\% of COVID-19 patients report confirmation of having gastrointestinal symptoms like nausea, vomiting, and diarrhea. The patients with these symptoms had overall more critical diseases (Jin et al. 2020; Lin et al. 2020). The discovery of gut microbiota and its metabolites may provide potential preventive and treatment targets for those who are susceptible to the COVID-19. In the future, they could serve as a potential therapeutic target for the development of drugs.

\section{Origin and colonization of COVID-19}

The severe acute respiratory syndrome coronavirus 2 (SARsCoV-2) has said to be originated from a place in China called
Wuhan as a case of severe unidentified pneumonia (Zhou et al. 2020). After by the confirmation of the virologists, named as Novel Coronavirus Pneumonia (NCP) which was caused by Novel Corona virus, later on, WHO officially named it as "Defined coronavirus disease"( COVID-19). Formal name and designation for the current disease was given based on communication conductivity in clinical and research trials (Wang et al. 2020). The virus belongs to a large class of prevalent viruses, $\beta$-corona virus family. Unlike other hosts, SARs-CoV-2 also has natural host, intermediate hosts, and final hosts which make the researcher in delaying to find the treatment with enormous challenges. SARs-CoV-2 has a high mortality and infectivity rate as compared to Middle East Respiratory Syndrome Corona Virus (MERS-CoV) (Zheng 2020). There are studies revealing interesting facts about the genomic sequences of the SARS-Cov-2 and Bat SARs corona virus (SARSr-CoV-RaTG13) were 79.5\% and $96 \%$ leading to an acute decision that the novel coronavirus would have spread from bats (Guo et al. 2020). According to the WHO, the first case of the novel coronavirus was reported on 12th December 2019.

The patient presented with most of the respiratory symptoms such as dry cough; dyspnoea; gastrointestinal problems such as nausea, vomiting, and diarrhea; fever; running nose; headache; abdominal discomfort; myalgia; and fatigue which are the common symptom criteria used to screen the novel corona virus disease (Shen et al. 2020). According to the published reports, bats are said to be the original natural host and reservoir of the infection; pangolins and snakes are said to be the intermediate hosts (Wan et al. 2020). Current scenario shows that patients infected with COVID-19 are the running source of infection. Droplets suspension in the air and close contact with a person infected with the COVID-19 may lead to the transmission of the current event (Galbadage et al. 2020). Reports studied the colonization of the virus in the lungs which are able to identify based on the gastrointestinal samples, sputum, saliva, and urine. Tears and conjunctival secretions are also said to be the main route of transmission from one individual to others (Mackenzie and Smith 2020; Xia et al. 2020).

The virus employed by damaging the internal lining of the alveoli and blood capillaries; the debris from the exasperations such as plasma proteins gets accumulated on the alveolar wall which results in the thickening of the internal lining (Guo et al. 2020). Due to the thickened internal lining of the alveolar sac, transfer of the oxygen in and out of the RBCs is made difficult for the domain, which results in difficulty of breathing as the concentration of the oxygen in the body is reduced. Hence, due to shortage of the oxygen supply to various organs of the body, there is impaired normal functioning of the body. At this stage, there is no immediate response from the human immune system due to lack of immunity to fight against the virus (Wang et al. 2020; Wu et al. 2020a). 


\section{Epidemiology and pathogenesis}

Recent report suggests that the SARs-CoV2 might be originated and transmitted from the bat as a potential reservoir and transmitter (Wu et al. 2020a). It is important to understand the severity and infectivity caused by the COVID-19 in the case of the human race. Based on the reports published by the WHO, $82 \%$ of the patients suffering from COVID-19 showed mild symptoms of the disease and interestingly, they recovered soon (Yuen et al. 2020). Also, children presented with very severe symptoms which were rated at $2.4 \%$ and are more prone to developing chronic diseases and mortality (Prill et al. 2012; Yuen et al. 2020). In addition to these facts, which supplements the patients who are suffering from the COVID-19 such as age, severe underlying disease, other secondary infections, and coinfections like the influenza virus, Klebsiella pneumoniae may lead to speed up the severity of the event (Chen et al. 2020a, pp. 2013-2019; Morris et al. 2017). So, it is important for the physician to screen out the individual based on some of the parameters such as hypoxia where the oxygen concentration in the blood is very much reduced, due to the abruption or the severe damage to the alveoli and alveolar trees. Shortness of breath and X-ray analysis of the lungs shows opaque to glassy appearances (Guo et al. 2020).

\section{Acute respiratory distress syndrome}

Acute respiratory distress syndrome (ARDSs) found in severe cases of the COVID-19 have a direct correlation between each other which may lead to enormous complications such as pneumonia, which is highly fatal. The patient presented with symptoms such as mucus less dry cough, shortened exchange of the gases in and out of the lungs, difficulty in breathing, and most importantly increased heart rate (Yi et al. 2020). If the individual is not suffering from ARDS, the severity of the COVID-19 in the individual is very less and can be treated with simple medications and speedy recovery. In addition to this, due to the severity of the infections from the COVID-19 and ARDS, an individual has a decreased or impaired immunity; once the individual gets infected with the ARDS, the scenario leads to pneumonia (Yuki et al. 2020).

COVID-19 can be differentiated into the different categories or the stages based on the carrier factors and symptoms in order to simply the severity of infection (Shi et al. 2020; Yuen et al. 2020). First category: these are the clear cut scene of the asymptomatic state of individuals where the domain is infected with the virus, but there is no sign of any infections due to lack of promisable symptoms, who acts as carriers. As the reports say, these are the major risk factors present in the society due to lack of knowledge in them and have higher chances of spreading the disease (Shi et al. 2020). Second category: individual presented with mild febrile illness, dry cough, headache, and conjunctivitis which are the common symptoms due to the abruptions in the upper respiratory tract. The third category, as said above in the second category, a similar presentation from the domain, but requires hospitalisation due to worsened respiratory systems. Chances of mortality are high, cures if treated. Fourth category: these are the severe case of the infection where fatality is very high, domain presented along with ARDS and pneumonia (Yuen et al. 2020).

The main function of the alveoli is to pump and transfer the oxygen to various blood capillaries; these capillaries transfer the oxygen to RBCs to all other internal organs of the body. On intervention of the COVID-19, these tiny air sacs of the alveoli get damaged and the process of the pumping of the oxygen thus reduced (Siordia 2020). Due to pneumonial damaged air sacs from the ARDSs, fluidic particles start secreting out of the ruptured cells and proteins which leads to the development of pneumonia. Furthermore, these systems imbalance the oxygen intake into the lungs which results in slow down of the oxygen exchange (Nathan et al. 2020; Siordia 2020).

\section{Microbiome-mediated crosstalk}

Many studies (Ubags and Marsland 2017; Zhang et al. 2020a; Sokolowska et al. 2018; Aarnoutse et al. 2019) observed that lung diseases such as asthma, COPD, cystic fibrosis, allergy, and lung cancer are associated with gut microbiome disturbances. Although, the clinical evidence for the impact of gut microbiota on lung infections, as well as diseases, is not fully understood. However, alteration in gut microbial metabolites and related species is found to be responsible for the changes in the lungs as inflammation responses as well as the disease development (Zhang et al. 2020a). During viral infection like the influenza virus, the injury was not caused by influenza infection; in fact, the intestinal injury was due to the migration of lymphocytes via CCL25-CCR9 axis from the respiratory tract into the intestinal mucosa (Table 1) (Dilantika et al. 2010). Therefore, analysis of microbiome in healthy individuals and under diseased conditions suggests that dysbiosis of gut microbiome has been linked with lung health and disease conditions (Fig. 1).

\section{Role of lung and gut microbiome in viral colonization}

The development of new technologies in culture-independent microbial analysis and identification uncovered the complexity of microbial interaction with the host. The complex communities in the various parts of the human body such as the lung, skin, or gut are observed with an appreciable role in maintaining immune homeostasis, organ, and tissue (Dickson et al. 2016). The lung and gut are constantly exposed to diverse microbiota, in fact, harbor abundant microbes which direct communication or crosstalk through various mechanism with lung or gut and collectively play a major role in host immunity (Belkaid and Hand 2014). Interestingly, microbial colonization in the human lung is tightly connected 
Table 1 Role of pathogenic bacteria on viral colonization in the lung and gut of the humans

\begin{tabular}{|c|c|c|c|c|c|}
\hline Bacteria & $\begin{array}{l}\text { Type of disease/ } \\
\text { infections }\end{array}$ & Viral infections & Type of colonization & Role/function & Reference \\
\hline \multicolumn{6}{|l|}{$\begin{array}{l}\text { Lung- microbiome } \\
\text { studies }\end{array}$} \\
\hline $\begin{array}{r}\text { Streptococcus } \\
\text { pneumoniae }\end{array}$ & Pneumonia & HRSV infection & $\begin{array}{l}\text { Opportunistic } \\
\text { colonization }\end{array}$ & $\begin{array}{l}\text { Exploit inflammation } \\
\text { and obtain nutrients }\end{array}$ & $\begin{array}{l}\text { Nguyen et al. } \\
\text { 2015; Bogaert et al. } \\
2004\end{array}$ \\
\hline $\begin{array}{l}\text { Staphylococcus } \\
\text { aureus }\end{array}$ & $\begin{array}{l}\text { Chronic respiratory } \\
\text { infections }\end{array}$ & $\begin{array}{l}\text { Rhinovirus, Influenza A } \\
\text { Virus }\end{array}$ & $\begin{array}{l}\text { Opportunistic } \\
\text { colonization }\end{array}$ & $\begin{array}{l}\text { Impaired mucociliary } \\
\text { clearance }\end{array}$ & $\begin{array}{l}\text { Dickson et al. 2013; } \\
\quad \text { Reddinger et al. } 2016\end{array}$ \\
\hline $\begin{array}{l}\text { Haemophilus } \\
\text { influenza }\end{array}$ & $\begin{array}{l}\text { Chronic respiratory } \\
\text { infections }\end{array}$ & $\begin{array}{l}\text { Epidemic Influenza, } \\
\text { Rhinovirus }\end{array}$ & $\begin{array}{l}\text { Opportunistic } \\
\text { colonization }\end{array}$ & $\begin{array}{l}\text { Mucociliary } \\
\text { interactions, } \\
\text { lung inflammation }\end{array}$ & King 2012 \\
\hline $\begin{array}{c}\text { Pseudomonas } \\
\text { aeruginosa }\end{array}$ & $\begin{array}{l}\text { Chronic respiratory } \\
\text { infections }\end{array}$ & Rhinovirus & $\begin{array}{l}\text { Opportunistic } \\
\text { colonization }\end{array}$ & Biofilm production & $\begin{array}{l}\text { Dickson et al. } \\
\text { 2013;Sörensen et al. } \\
2020\end{array}$ \\
\hline $\begin{array}{l}\text { Burkholderia } \\
\text { cepacia }\end{array}$ & $\begin{array}{l}\text { Chronic respiratory } \\
\text { infections }\end{array}$ & Influenza virus & $\begin{array}{l}\text { Opportunistic } \\
\text { colonization }\end{array}$ & Biofilm production & $\begin{array}{l}\text { Dickson et al. 2013; } \\
\text { Fung et al. } 1998\end{array}$ \\
\hline $\begin{array}{l}\quad \text { Klebsiella } \\
\quad \text { pneumoniae } \\
\text { K. oxytoca } \\
\text { Gut- microbiome } \\
\quad \text { studies }\end{array}$ & Pneumonia & Influenza A virus & $\begin{array}{l}\text { Opportunistic } \\
\text { colonization }\end{array}$ & Biofilm production & $\begin{array}{l}\text { Lee et al. 2018; Lee et al. } \\
\quad 2015\end{array}$ \\
\hline $\begin{array}{l}\text { Clostridium } \\
\text { difficile }\end{array}$ & $\begin{array}{l}\text { Acute infectious } \\
\text { diarrhea }\end{array}$ & $\begin{array}{l}\text { Norovirus genogroup 2, } \\
\text { Sapovirus, Astrovirus }\end{array}$ & $\begin{array}{l}\text { Opportunistic colonization } \\
\text { or contaminated food }\end{array}$ & $\begin{array}{l}\text { Release toxins that } \\
\text { damage the cells } \\
\text { lining the intestinal } \\
\text { wall }\end{array}$ & $\begin{array}{c}\text { Dickson et al. 2013; El } \\
\text { Feghaly et al. } 2013\end{array}$ \\
\hline $\begin{array}{l}\text { Faecalibacterium } \\
\text { prausnitzii }\end{array}$ & $\begin{array}{l}\text { Inflammatory } \\
\text { bowel disease }\end{array}$ & Bacteriophages & Opportunistic colonization & Interstitial inflammation & Cornuault et al. 2018 \\
\hline $\begin{array}{l}\text { Campylobacter } \\
\text { enteritis }\end{array}$ & Traveler's diarrhea & Viral gastroenteritis & Contaminated food & $\begin{array}{l}\text { Toxin produced disrupt } \\
\text { epithelial lining }\end{array}$ & Janssen et al. 2008 \\
\hline $\begin{array}{r}\text { Pasteurella } \\
\text { multocida }\end{array}$ & $\begin{array}{l}\text { Acute and chronic } \\
\text { infections in gut }\end{array}$ & $\begin{array}{l}\text { Bovine respiratory } \\
\text { syncytial virus }\end{array}$ & Opportunistic colonization & Biofilm formation, & $\begin{array}{l}\text { Sudaryatma et al. 2018; } \\
\text { Wilson and Ho } 2013\end{array}$ \\
\hline
\end{tabular}

with its anatomy and physiological function (Mathieu et al. 2018). It has been observed that microbial diversity transition from the upper to the lower respiratory tract depends upon gradients of pressure and temperature change. Moreover, colonization of microbes in both lung and gut also depends on the age and other respective physiological conditions (Milani et al. 2017; Shastry and Rekha 2020).

The human gut provides opportunities for the colonization of viruses and other microbes starting from the oral cavity, through the esophagus, stomach, small intestine, colon, and rectum (Hillman et al. 2017). The healthy gut is typically dominated by bacteria belonging to the genera Bacteroides, Faecalibacterium, and Bifidobacterium (Barcik et al. 2020). Different studies on the human gut microbiome concluded with various microbes besides bacteria and fungi (Shastry and Rekha 2020), additionally, microbiota composed of viruses and archaea (Thursby and Juge 2017). The viruses mainly belong to bacteriophages and the archaeal population is dominated by Methanobrevibacter smithii (Barcik et al. 2020). Many studies in human and mouse model demonstrate the axis between the lung and gut through gut-associated lymphoid tissue (GALT) and inducible bronchus-associated lymphoid tissue (iBALT), which are part of the regulation of local immune responses (Hwang et al. 2016; Tan et al. 2019). The GALT and iBALT involve in the $\mathrm{T}_{\mathrm{h}}$ cell and cytotoxic $\left(\mathrm{T}_{\mathrm{c}}\right)$ responses through the production and secretion of $\operatorname{IgA}$ at mucosal surfaces (McGhee and Fujihashi 2012). The connection between the lung and gut through microbiome is an observation influenced by lung diseases and intestinal microbiome changes and vice versa (Zhang et al. 2020a).

The mechanism in the communication between lung-gut is still unclear, but the regulation through normal microbiota and dysbiosis suggested that metabolites (short-chain fatty acids, SCFAs), colonization induced immunity and other protective functions significantly influence on viral colonization in the human lungs (Barcik et al. 2020). A recent study on patients undergoing allogeneic hematopoietic stem cell transplantation (allo-HCT) found a significant correlation of impact on colonization of the gut with butyrate-producing microbiota on the prevalence of lower respiratory tract infection (LRTI). The 
Fig. 1 Possible gut-lung crosstalk in respiratory viral infections. Respiratory viral infections mediate migration of lymphocyte from the respiratory tract into the intestinal mucosa which can induce intestinal injury (Dilantika et al. 2010). Dysbiosis can increase intestinal permeability as well as alter metabolite production in the gut, which lead to an increased exacerbation of pre-existing lung disease or risk for respiratory diseases

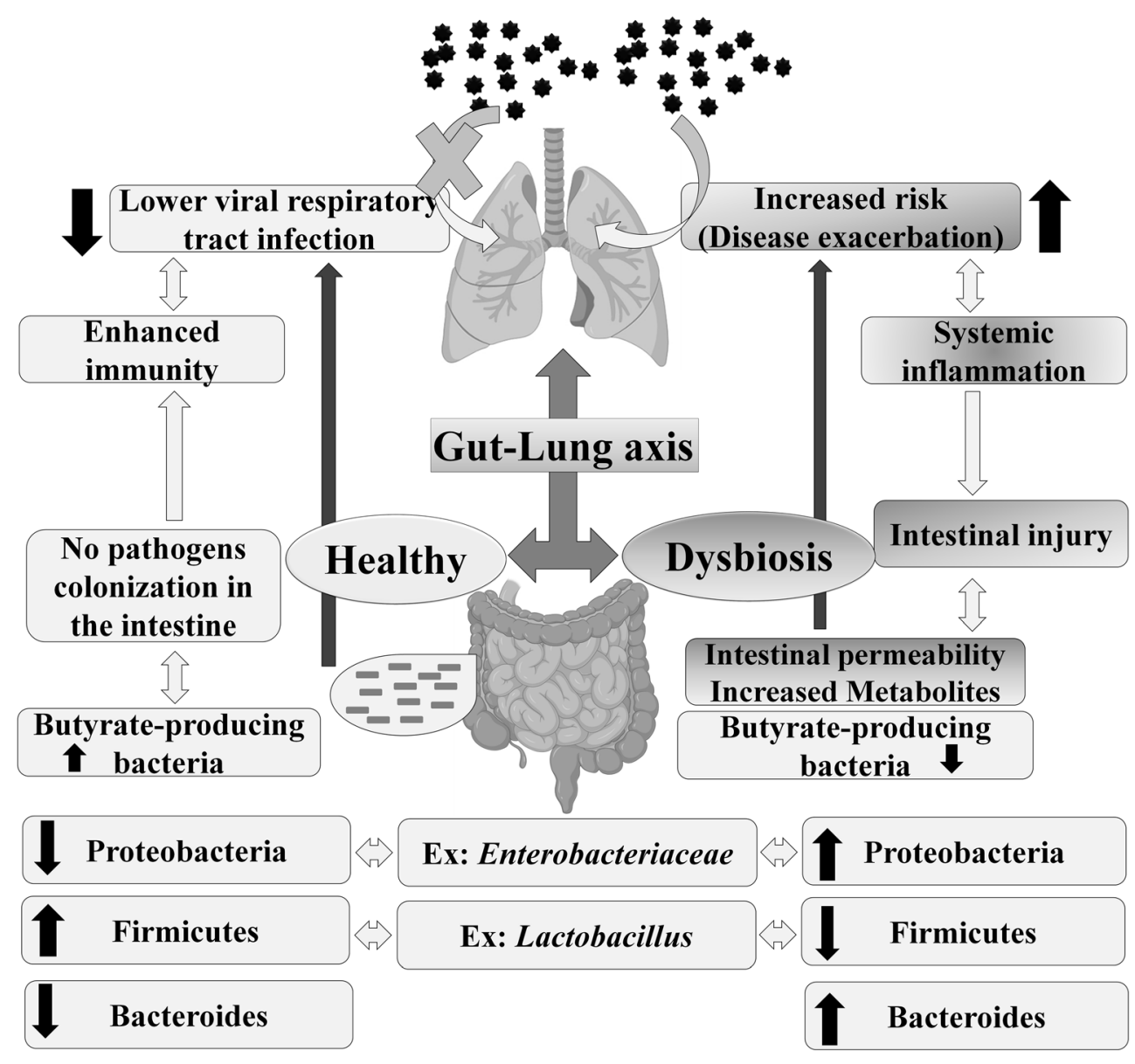

A recent study showed that there is a structural similarity between the receptors-binding complex of SARS and COVID-19, which means COVID-19 uses ACE2 as a receptor (Zhang et al. 2020b). ACE2 is seen in an enormous amount in epithelial walls of the human lung and intestine, and based on the reports, these receptors are present on the luminal surface of small intestinal epithelial wall especially in the crypts and colon (Hamming et al. 2004). In addition, these are also linked with the amino acid transport function of the of ACE2 to the microbial population in the GI tract, where the ACE2 mutants get lesser peptides to bind, hence show the altered gut microbial population (Hashimoto et al. 2012). The respiratory tract has its own microbiota, but patients who are suffering from respiratory infections will always be suffering from the GIT dysfunction which is very severe in most of cases revealing the gut-lung crosstalk (Enaud et al. 2020). Various reports share the information of microbial population present in the gut which may alter many other respiratory tract infections caused such as ventilator-associated pneumonia (Dickson et al. 2013). Since now, there is no direct clinical evidence of the gut microbiome, which plays a role in the alteration in moduling the severity caused by the COVID-19. However, respiratory infection patients generally have gut dysfunction complications with a more severe clinical course of the 
disease, indicating possible gut-lung crosstalk due to dysbiosis or treatment complications.

ACE2 is specifically located on the surface of the luminal intestinal epithelial cells and gut microbiota influences the activity of ACE2 (Perlot and Penninger 2013). Therefore, it is hypothesized that there is a close relationship between the COVID-19 and the gut microbiota. Even a small quantity of the bacteria present in the alveoli contributes to the equilibrium maintenance of the lung immune system. The gut bacteria producing lactic acid by Lactobacilli increase the antiviral immune response and activity of natural killer cells (Feng et al. 2020). It is possible that novel targeted approaches to modulate microbiota of the gut as one of the best therapeutic approaches of COVID-19 and its comorbidities.

Emerging investigations indicate that gut-lung axis is a fundamental cross-talk between gut and lungs microbiota. Microbiota that inhabits in both lung and gut lives in a mutualistic approach with the host. In the gut microbial communities, Firmicutes and Bacteroidetes are more predominant, while Firmicutes, Bacteroidetes, and Proteobacteria dominate in the lung (Marsland et al. 2015). A well-balanced gut microbial community is of immense importance in the functioning of a good immune system and health (McAleer and Kolls 2018). The gut microbiome has been reported to play an important role in pulmonary immunity via vital cross-talk between the lungs and gut microbiota (Keely et al. 2012). The gut-lung axis allows the transport/diffusion of microbial metabolites, endotoxins, and cytokines into the bloodstream linking the gut and the lung. Few reports evidenced that the involvement of Toll-like receptors (TLRs) (Wang et al. 2018), T cell subsets (Luu et al. 2017) and inflammation cytokines and surfactant protein D (Du et al. 2018), and some other factors have been reported as the essential mechanisms. However, probiotics, prebiotics, antibiotics, natural products, or food diets have been attempted clinical and laboratory studies in different lung diseases as new therapeutic strategies that target alteration of the gut microbiome (Vieira et al. 2016).

The microbiome has become identical for the collection of bacterial species as well as fungal diversity or mycobiome is an important part of the microbiome (Seed 2014). Approximately, 400 different fungi have been isolated and identified from humans (Halwachs et al. 2017) and the biomass constitutes a number of biologically active compounds, which might significantly influence on host immune system (Underhill and Iliev 2014). Particularly, the gut mycobiota has been proved to alter the innate immune system of the host via Dectin-1 receptor (Iliev et al. 2012). Dysbiosis of gut fungal diversity has been linked with gut inflammation, particularly colitis exacerbation, observed in antifungal drug-treated mice (Wheeler et al. 2016). Some native microbiome like Lactobacillus salivarius also reported to produce in mice that can considerably protect mice against pathogenic Listeria monocytogenes. Most importantly, protection was also observed against the naturally bacteriocin-resistant foodborne pathogen, such as Salmonella typhimurium (Corr et al. 2007).

The significance of the microbiome in modifying the innate immune system in life occurs from several studies comparing germ-free and specific pathogen-free mice. Germ-free mice are categorized by with immature mesenteric lymph nodes, few germinal centers, few lymphoid follicles, decreased quantity of antimicrobial peptides, decreased immunoglobulin (Ig A), and an overall decreased B, T, and dendritic cells (Sommer and Bäckhed 2013). Furthermore, they observed defects in the systemic immune system, since the spleen and lymph node structures are affected with less germinal centers, diffuse $\mathrm{B}$ and $\mathrm{T}$ cell zones, and low levels of circulating $\mathrm{IgG}$. Interestingly, colonizing germ-free mice with commensal bacterial species reversed the defects, then developed normal immune system and normalized within a few weeks (Macpherson and Harris 2004).

Recent studies on modulating gut microbiota suggest that it can reduce ventilator-associated pneumonia and enteritis; in some cases, it can reverse side effects of antibiotics during treatment of early influenza virus replication in lung epithelia (Shimizu et al. 2018). Two randomized control trials on mechanical ventilated patients developed substantially less pneumonia with the supplementation of probiotics such as Lactobacillus rhamnosus GG, live Bacillus subtilis, and Enterococcus faecalis (Morrow et al. 2010; Zeng et al. 2016). Moreover, for patients with severe COVID-19 infection, the National Administration of Traditional Chinese Medicine and China's National Health Commission recommended probiotics in the treatment as it used to prevent secondary bacterial infection and maintain balance in the intestinal microecology (Gao et al. 2020).

\section{Microbiome immunity}

Microorganisms protect our health by inducing our immune system to fight against infectious diseases including viral infections and a healthy gut microbiome also helps to protect dangerous immune over-reactions in the host that damages the lungs, heart, and other vital organs (Belkaid and Hand 2014). Due to this, excessive immune response may also cause respiratory failure and deaths in several infectious diseases. The normal microbiota constitutes microorganisms that live on the surface of the skin, mouth, gastrointestinal and genitourinary tract, and respiratory system. This microbiota interacts with our cells and most of our health depends on our immune system responses to infectious diseases (Lazar et al. 2018). During viral infections, our body responds to infection initially by activating the innate and adaptive immune system. These two mechanisms limit the multiplication of the virus and help to eliminate infectious pathogens. But, few viruses have evolved to develop mechanisms to evade the host 
immune response, as observed in SARS-CoV-2, which is responsible for current pandemic COVID-19 (Kumar et al. 2020; Tay et al. 2020).

The human body nurtures a vast number of microorganisms, such as viruses, bacteria, and fungi, which lives on its both internal and external surface. Research reports evidenced that colonization of microbial cells in mucosal tissues during childhood is more important for the maintenance, balancing, and development of the immune system (Gensollen et al. 2016). Dysbiosis of the gut microbiota has been linked with the development of a number of infectious diseases and also non-infectious diseases including allergy, asthma, and COPD (Sokolowska et al. 2018). Modified gut microbiota on viral respiratory infections have been reported in several studies (Hanada et al. 2018; Li et al. 2019; Grayson et al. 2018; Demirci et al. 2019). In an experiment, C57BL6 mice was treated with antibiotic streptomycin before infection with the murine paramyxovirus type 1 . A drastic reduction was observed in microbial diversity of the intestine, without effecting on lung microbial diversity after the treatment of streptomycin. Reduction in microbial diversity in the intestine was resulted in significantly increased mortality rate to respiratory viral infection (Grayson et al. 2018). The increased mortality to respiratory infection was connected with a low immune response characterized by an increase in lung IL-6, IFN- $\gamma$, and CCL2 simultaneously decrease in count of regulatory Tcells (Tregs) in the lungs and intestinal tract (Zhang et al. 2020a). In healthy humans, the most common group's intestinal microbiota are genera Bifidobacteria, Bacteroides, and Faecalibacterium (Robles Alonso and Guarner 2013). The lower respiratory tract of the human body is one of the less microbial populated surfaces with an approximately 10 to 100 bacterial cells per 1000 human cells (Sze et al. 2012). The major bacterial groups detected in the lung airways are Bacteroidetes and Firmicutes; there are minor groups including Proteobacteria, Actinobacteria, and Fusobacteria within their local microbiota (Erb-Downward et al. 2011; Hilty et al. 2010). In a recent report, the mechanism correlated with the microbiota of the intestine and lung interaction in immune response to the infection of Mycobacterium tuberculosis has been explored (Negi et al. 2019).

For the several years, the lung was considered to be a sterile organ but many publications have been proved that it harbors its own microbiota (Dickson et al. 2016; Huffnagle et al. 2017; Erb-Downward et al. 2011; Hilty et al. 2010). Several studies reported that the lungs of healthy individuals are most abundant with the phyla Proteobacteria (Acinetobacter sp.), Actinobacteria (Corynebacterium sp.), and Firmicutes (Streptococcus sp.) (Bassis et al. 2015; Venkataraman et al. 2015; Aarnoutse et al. 2019). Immunity has been known to play a very important role in the cause of pathogenesis in asthma. In this, the involvement of TLRs and regulatory $\mathrm{T}$ cell subsets is linked between gut microbiota, and allergy was hypothesized. In a recent investigation, bacterial DNA extracted from the stool samples of 88 healthy children and 92 children diagnosed with asthma were detected. Results revealed that Faecalibacterium prausnitzii and Akkermansia muciniphila was observed to be decreased in asthma patients when compared to the healthy group. These two bacteria may suppress the lung inflammation by modulating secreted bacterial metabolites, such as the decreased amount of IL-12 and increased IL-10 (Demirci et al. 2019).

Several reports indicated that gut-liver-lung crosstalk plays an essential role in the development of COPD (Young et al. 2016; Kuo 2013: Zhuang et al. 2019). The liver is one of the key organs generating inflammatory cytokines and mediators as an innate-immune response in other parts including the lung and gut (Jenne and Kubes 2013). Subsequently, increasing evidence suggested that the gut is linked to the liver and lungs via dietary factors (Kuo 2013). In another study, it was found that a decrease in levels of Actinobacteria sp. and Bifidobacterium sp. and an increase in levels of Enterococcus sp. were linked with lung cancer disease (Aarnoutse et al. 2019). In addition, the destruction of the normal function of the gut microbial diversity impacts on lung cancer progression. An essential cross-talk between the lung and gut microbiome has been reported in the progression of lung diseases. The gut-lung axis allows for the movement of cytokines, microbial metabolites, endotoxins, and hormones into the bloodstream connecting with the gut niche and lung (Zhuang et al. 2019).

It was also observed the change of intestinal microenvironment in different lung diseases and also variations in the diversity of intestinal microbiota (Zhang et al. 2020a). This is a clear indication of their vital cross-talk between the lungs and intestine. A number of studies in recent days have been focused on the microbiota of the intestine during chronic respiratory diseases. In one of the studies, $\mathrm{Yi}$ and colleagues compared the bacterial diversity of the healthy individuals in the upper respiratory tract with patients infected with the respiratory syncytial virus (RSV), parainfluenza, influenza, adenovirus, rhinovirus, and coronavirus (Yi et al. 2014). Virusinfected patients generally confirmed an increased occurrence of Haemophilus and Moraxella. Molyneaux et al. (2013) demonstrated that healthy subjects with rhinovirus infection do not alter the composition of the microbiota in induced-sputum samples. COPD patients infected with rhinovirus can only be seen an outgrowth of pathogenic bacteria, mainly of the Proteobacteria phylum (e.g., H. influenzae); this suggests secondary bacterial infections due to their predisposition. In recent findings, it has confirmed that the intestine microbiome can play a vital role in inducing immune responses in both local and outside location, including the lungs. This could be done by the systemic distribution of bacterial metabolites; these are produced in the intestine but can reach different organs through the bloodstream and exert their anti- 
inflammatory role (Belkaid and Hand 2014). Understanding of the gut-lung axis in respiratory disease has been recognized in recent years. Importantly, the existence of this mechanism opens up new hopes for the development of therapeutic approaches to COVID-19 and other respiratory infections (Dhar and Mohanty 2020).

\section{Conclusions}

In viral respiratory infections, alternations in the microbial composition of the airway and intestinal microbiota are observed, commonly due to the major outgrowth of Proteobacteria and Bacteroides. A microbiome-mediated cross-talk along the gutlung axis has been noted during lung infection specifically due to alterations in the gut microbial species and metabolites. However, clinical evidence-based mechanism by which the gut impacts the lung environment and viral infection has not yet fully understood. But, microbial metabolites such as SCFAs and probiotic microbes influence the immune responses as well as in preventing pathogen colonization. Interestingly, patients with respiratory infections and diseases generally observed with gut dysbiosis and related complications indicating gut-lung crosstalk. In COVID-19 patients, this phenomenon can also be observed. Therefore, improving gut microbiota with probiotics and other beneficial bacteria plays a major role in therapeutic applications and this could be further extended in the treatment of COVID-19 as a new therapeutic approach.

Funding R. P. Shastry was supported by the Yenepoya (Deemed to be University) Seed grant (YU/Seed grant/080-2019).

\section{Compliance with ethical standards}

Conflict of interest The authors declare that they have no conflict of interest.

\section{References}

Aarnoutse R, Ziemons J, Penders J, Rensen SS, de Vos-Geelen J, Smidt ML. The clinical link between human intestinal microbiota and systemic cancer therapy. Int J Mol Sci. 2019;20. https://doi.org/10. 3390/ijms20174145.

Barcik W, Boutin RCT, Sokolowska M, Finlay BB. The role of lung and gut microbiota in the pathology of asthma. Immunity. 2020;52:24155. https://doi.org/10.1016/j.immuni.2020.01.007.

Bassis CM, Erb-Downward JR, Dickson RP, Freeman CM, Schmidt TM, Young VB, et al. Analysis of the upper respiratory tract microbiotas as the source of the lung and gastric microbiotas in healthy individuals. MBio. 2015;6:e00037. https://doi.org/10.1128/mBio.00037-15.

Belkaid Y, Hand T. Role of the microbiota in immunity and inflammation. Cell. 2014;157:121-41. https://doi.org/10.1016/j.cell.2014.03.011.

Bogaert D, van Belkum A, Sluijter M, Luijendijk A, de Groot R, Rümke HC, et al. Colonisation by Streptococcus pneumoniae and Staphylococcus aureus in healthy children. Lancet Lond Engl. 2004;363:1871-2. https://doi.org/10.1016/S0140-6736(04)16357-5.
Chavez S, Long B, Koyfman A, Liang SY. Coronavirus Disease (COVID-19): a primer for emergency physicians. Am J Emerg Med. 2020. https://doi.org/10.1016/j.ajem.2020.03.036.

Chen L, Han X-D, Li Y-L, Zhang C-X, Xing X-Q. Severity and outcomes of influenza-related pneumonia in type A and B strains in China, 2013-2019. Infect Dis Poverty. 2020a;9:42. https://doi.org/10.1186/ s40249-020-00655-w.

Chen N, Zhou M, Dong X, Qu J, Gong F, Han Y, et al. Epidemiological and clinical characteristics of 99 cases of 2019 novel coronavirus pneumonia in Wuhan, China: a descriptive study. Lancet Lond Engl. 2020b;395:507-13. https://doi.org/10.1016/S0140-6736(20) 30211-7.

Cole-Jeffrey CT, Liu M, Katovich MJ, Raizada MK, Shenoy V. ACE2 and microbiota: emerging targets for cardiopulmonary disease therapy. J Cardiovasc Pharmacol. 2015;66:540-50. https://doi.org/10. 1097/FJC.0000000000000307.

Cornuault JK, Petit M-A, Mariadassou M, Benevides L, Moncaut E, Langella $\mathrm{P}$, et al. Phages infecting Faecalibacterium prausnitzii belong to novel viral genera that help to decipher intestinal viromes. Microbiome. 2018;6:65. https://doi.org/10.1186/s40168-018-04521.

Corr SC, Li Y, Riedel CU, O'Toole PW, Hill C, Gahan CGM. Bacteriocin production as a mechanism for the antiinfective activity of Lactobacillus salivarius UCC118. Proc Natl Acad Sci U S A. 2007;104:7617-21. https://doi.org/10.1073/pnas.0700440104.

Cui J, Li F, Shi Z-L. Origin and evolution of pathogenic coronaviruses. Nat Rev Microbiol. 2019;17:181-92. https://doi.org/10.1038/ s41579-018-0118-9.

Demirci M, Tokman HB, Uysal HK, Demiryas S, Karakullukcu A, Saribas S, et al. Reduced Akkermansia muciniphila and Faecalibacterium prausnitzii levels in the gut microbiota of children with allergic asthma. Allergol Immunopathol (Madr). 2019;47:36571. https://doi.org/10.1016/j.aller.2018.12.009.

Dhar D, Mohanty A. Gut microbiota and Covid-19- possible link and implications. Virus Res. 2020:198018. https://doi.org/10.1016/j. virusres.2020.198018.

Dickson RP, Erb-Downward JR, Huffnagle GB. The role of the bacterial microbiome in lung disease. Expert Rev Respir Med. 2013;7:24557. https://doi.org/10.1586/ers.13.24.

Dickson RP, Erb-Downward JR, Martinez FJ, Huffnagle GB. The microbiome and the respiratory tract. Annu Rev Physiol. 2016;78: 481-504. https://doi.org/10.1146/annurev-physiol-021115-105238.

Dilantika C, Sedyaningsih ER, Kasper MR, Agtini M, Listiyaningsih E, Uyeki TM, et al. Influenza virus infection among pediatric patients reporting diarrhea and influenza-like illness. BMC Infect Dis. 2010;10:3. https://doi.org/10.1186/1471-2334-10-3.

Du J, Abdel-Razek O, Shi Q, Hu F, Ding G, Cooney RN, et al. Surfactant protein $\mathrm{D}$ attenuates acute lung and kidney injuries in pneumoniainduced sepsis through modulating apoptosis, inflammation and NF-KB signaling. Sci Rep. 2018;8:1-14. https://doi.org/10.1038/ s41598-018-33828-7.

El Feghaly RE, Stauber JL, Tarr PI, Haslam DB. Viral Co-infections are common and are associated with higher bacterial burden in children with $C$. difficile infection. J Pediatr Gastroenterol Nutr. 2013;57: 813-6. https://doi.org/10.1097/MPG.0b013e3182a3202f.

Enaud R, Prevel R, Ciarlo E, Beaufils F, Wieërs G, Guery B, et al. The gut-lung axis in health and respiratory diseases: a place for interorgan and inter-kingdom crosstalks. Front Cell Infect Microbiol. 2020;10. https://doi.org/10.3389/fcimb.2020.00009.

Erb-Downward JR, Thompson DL, Han MK, Freeman CM, McCloskey L, Schmidt LA, et al. Analysis of the lung microbiome in the "healthy" smoker and in COPD. PLoS One. 2011;6:e16384. https://doi.org/10.1371/journal.pone.0016384.

Feng Z, Wang Y, Qi W. The small intestine, an underestimated site of SARS-CoV-2 Infection: from red queen effect to probiotics. 2020. https://doi.org/10.20944/preprints202003.0161.v1. 
Fung SK, Dick H, Devlin H, Tullis E. Transmissibility and infection control implications of Burkholderia cepacia in cystic fibrosis. Can J Infect Dis. 1998;9:177-82.

Galbadage T, Peterson BM, Gunasekera RS. Does COVID-19 spread through droplets alone? Front Public Health. 2020;8. https://doi. org/10.3389/fpubh.2020.00163.

Gao QY, Chen YX, Fang JY. 2019 Novel coronavirus infection and gastrointestinal tract. J Dig Dis. 2020;21:125-6. https://doi.org/10. 1111/1751-2980.12851.

Gasmi A, Noor S, Tippairote T, Dadar M, Menzel A, Bjørklund G. Individual risk management strategy and potential therapeutic options for the COVID-19 pandemic. Clin Immunol Orlando Fla. 2020;215:108409. https://doi.org/10.1016/j.clim.2020.108409.

Gensollen T, Iyer SS, Kasper DL, Blumberg RS. How colonization by microbiota in early life shapes the immune system. Science. 2016;352:539-44. https://doi.org/10.1126/science.aad9378.

Grayson MH, Camarda LE, Hussain S-RA, Zemple SJ, Hayward M, Lam $\mathrm{V}$, et al. Intestinal microbiota disruption reduces regulatory $\mathrm{T}$ cells and increases respiratory viral infection mortality through increased IFN $\gamma$ production. Front Immunol. 2018;9:1587. https://doi.org/10. 3389/fimmu.2018.01587.

Guo Y-R, Cao Q-D, Hong Z-S, Tan Y-Y, Chen S-D, Jin H-J, et al. The origin, transmission and clinical therapies on coronavirus disease 2019 (COVID-19) outbreak - an update on the status. Mil Med Res. 2020;7:11. https://doi.org/10.1186/s40779-020-00240-0.

Gupta V, Haider S, Verma M, Ponnusamy K, Malik MZ, Singhvi N, et al. Multi-omics and integrated network approach to unveil evolutionary patterns, mutational hotspots, functional crosstalk and regulatory interactions in SARS-CoV-2. BioRxiv. 2020:2020.06.20.162560. https://doi.org/10.1101/2020.06.20.162560.

Haak BW, Littmann ER, Chaubard J-L, Pickard AJ, Fontana E, Adhi F, et al. Impact of gut colonization with butyrate-producing microbiota on respiratory viral infection following allo-HCT. Blood. 2018;131: 2978-86. https://doi.org/10.1182/blood-2018-01-828996.

Halwachs B, Madhusudhan N, Krause R, Nilsson RH, Moissl-Eichinger $\mathrm{C}$, Högenauer $\mathrm{C}$, et al. Critical issues in mycobiota analysis. Front Microbiol. 2017;8:180. https://doi.org/10.3389/fmicb.2017.00180.

Hamming I, Timens W, Bulthuis MLC, Lely AT, Navis GJ, van Goor H. Tissue distribution of ACE2 protein, the functional receptor for SARS coronavirus. A first step in understanding SARS pathogenesis. J Pathol. 2004;203:631-7. https://doi.org/10.1002/path.1570.

Hanada S, Pirzadeh M, Carver KY, Deng JC. Respiratory viral infectioninduced microbiome alterations and secondary bacterial pneumonia. Front Immunol. 2018;9:2640. https://doi.org/10.3389/fimmu.2018. 02640 .

Hashimoto T, Perlot T, Rehman A, Trichereau J, Ishiguro H, Paolino M, et al. ACE2 links amino acid malnutrition to microbial ecology and intestinal inflammation. Nature. 2012;487:477-81. https://doi.org/ 10.1038/nature11228.

Hillman ET, Lu H, Yao T, Nakatsu CH. Microbial Ecology along the gastrointestinal tract. Microbes Environ. 2017;32:300-13. https:// doi.org/10.1264/jsme2.ME17017.

Hilty M, Burke C, Pedro H, Cardenas P, Bush A, Bossley C, et al. Disordered microbial communities in asthmatic airways. PLoS One. 2010;5:e8578. https://doi.org/10.1371/journal.pone.0008578.

Hindson J. COVID-19: faecal-oral transmission? Nat Rev Gastroenterol Hepatol. 2020;1:259. https://doi.org/10.1038/s41575-020-0295-7.

Hu Y, Shen L, Yao Y, Xu Z, Zhou J, Zhou H. A report of three COVID19 cases with prolonged viral RNA detection in anal swabs. Clin Microbiol Infect. 2020;26:786-7. https://doi.org/10.1016/j.cmi. 2020.04.010.

Huang C, Wang Y, Li X, Ren L, Zhao J, Hu Y, et al. Clinical features of patients infected with 2019 novel coronavirus in Wuhan, China. Lancet Lond Engl. 2020;395:497-506. https://doi.org/10.1016/ S0140-6736(20)30183-5.
Huffnagle GB, Dickson RP, Lukacs NW. The respiratory tract microbiome and lung inflammation: a two-way street. Mucosal Immunol. 2017;10:299-306. https://doi.org/10.1038/mi.2016.108.

Hwang JY, Randall TD, Silva-Sanchez A. Inducible bronchus-associated lymphoid tissue: taming inflammation in the lung. Front Immunol. 2016;7. https://doi.org/10.3389/fimmu.2016.00258.

Iliev ID, Funari VA, Taylor KD, Nguyen Q, Reyes CN, Strom SP, et al. Interactions between commensal fungi and the $\mathrm{C}$-type lectin receptor Dectin-1 influence colitis. Science. 2012;336:1314-7. https:// doi.org/10.1126/science.1221789.

Janssen R, Krogfelt KA, Cawthraw SA, van Pelt W, Wagenaar JA, Owen RJ. Host-pathogen interactions in campylobacter infections: the host perspective. Clin Microbiol Rev. 2008;21:505-18. https://doi.org/ 10.1128/CMR.00055-07.

Jenne CN, Kubes P. Immune surveillance by the liver. Nat Immunol. 2013;14:996-1006. https://doi.org/10.1038/ni.2691.

Jin X, Lian J-S, Hu J-H, Gao J, Zheng L, Zhang Y-M, et al. Epidemiological, clinical and virological characteristics of 74 cases of coronavirus-infected disease 2019 (COVID-19) with gastrointestinal symptoms. Gut. 2020;69:1002-9. https://doi.org/10.1136/ gutjnl-2020-320926.

Keely S, Talley NJ, Hansbro PM. Pulmonary-intestinal cross-talk in mucosal inflammatory disease. Mucosal Immunol. 2012;5:7-18. https://doi.org/10.1038/mi.2011.55.

King P. Haemophilus influenzae and the lung (Haemophilus and the lung). Clin Transl Med. 2012;1:10. https://doi.org/10.1186/20011326-1-10.

Kumar S, Nyodu R, Maurya VK, Saxena SK. Host Immune response and immunobiology of human SARS-CoV-2 infection. In: Saxena SK, editor. Coronavirus Dis. 2019 COVID-19 Epidemiol. Pathog. Diagn. Ther. Singapore: Springer; 2020. p. 43-53.

Kuo S-M. The interplay between fiber and the intestinal microbiome in the inflammatory response. Adv Nutr Bethesda Md. 2013;4:16-28. https://doi.org/10.3945/an.112.003046.

Lazar V, Ditu L-M, Pircalabioru GG, Gheorghe I, Curutiu C, Holban $\mathrm{AM}$, et al. Aspects of gut microbiota and immune system interactions in infectious diseases, immunopathology, and cancer. Front Immunol. 2018;9. https://doi.org/10.3389/fimmu.2018.01830.

Lee B, Robinson KM, McHugh KJ, Scheller EV, Mandalapu S, Chen C, et al. Influenza-induced type I interferon enhances susceptibility to gram-negative and gram-positive bacterial pneumonia in mice. Am J Physiol-Lung Cell Mol Physiol. 2015;309:L158-67. https://doi.org/ 10.1152/ajplung.00338.2014.

Lee KM, Morris-Love J, Cabral DJ, Belenky P, Opal SM, Jamieson AM. Coinfection with influenza A virus and Klebsiella oxytoca: an underrecognized impact on host resistance and tolerance to pulmonary infections. Front Immunol. 2018;9. https://doi.org/10.3389/ fimmu.2018.02377.

Li N, Ma W-T, Pang M, Fan Q-L, Hua J-L. The commensal microbiota and viral infection: a comprehensive review. Front Immunol. 2019;10:1551. https://doi.org/10.3389/fimmu.2019.01551.

Lin L, Jiang X, Zhang Z, Huang S, Zhang Z, Fang Z, et al. Gastrointestinal symptoms of 95 cases with SARS-CoV-2 infection. Gut. 2020;69:997-1001. https://doi.org/10.1136/gutjnl-2020321013.

Liu K, Chen Y, Lin R, Han K. Clinical features of COVID-19 in elderly patients: a comparison with young and middle-aged patients. J Inf Secur. 2020;80:e14-8. https://doi.org/10.1016/j.jinf.2020.03.005.

Luu M, Steinhoff U, Visekruna A. Functional heterogeneity of gutresident regulatory T cells. Clin Transl Immunol. 2017;6:e156. https://doi.org/10.1038/cti.2017.39.

Mackenzie JS, Smith DW. COVID-19: a novel zoonotic disease caused by a coronavirus from China: what we know and what we don't. Microbiol Aust. 2020;41:45. https://doi.org/10.1071/MA20013. 
Macpherson AJ, Harris NL. Interactions between commensal intestinal bacteria and the immune system. Nat Rev Immunol. 2004;4:478-85. https://doi.org/10.1038/nri1373.

Mandal S, Singh RKS, Sharma SK, Malik MZ, Singh RKB. Complexity in SARS-CoV-2 genome data: price theory of mutant isolates. BioRxiv. 2020:2020.05.04.077511. https://doi.org/10.1101/2020. 05.04.077511.

Marsland BJ, Trompette A, Gollwitzer ES. The gut-lung axis in respiratory disease. Ann Am Thorac Soc. 2015;12(Suppl 2):S150-6. https://doi.org/10.1513/AnnalsATS.201503-133AW.

Mathieu E, Escribano-Vazquez U, Descamps D, Cherbuy C, Langella P, Riffault S, et al. Paradigms of lung microbiota functions in health and disease, particularly, in asthma. Front Physiol. 2018;9. https:// doi.org/10.3389/fphys.2018.01168.

McAleer JP, Kolls JK. Contributions of the intestinal microbiome in lung immunity. Eur J Immunol. 2018;48:39-49. https://doi.org/10.1002/ eji.201646721

McGhee JR, Fujihashi K. Inside the mucosal immune system. PLoS Biol. 2012;10:e1001397. https://doi.org/10.1371/journal.pbio.1001397.

Milani C, Duranti S, Bottacini F, Casey E, Turroni F, Mahony J, et al. The first microbial colonizers of the human gut: composition, activities, and health implications of the infant gut microbiota. Microbiol Mol Biol Rev MMBR. 2017;81. https://doi.org/10.1128/MMBR.0003617.

Molyneaux PL, Mallia P, Cox MJ, Footitt J, Willis-Owen SAG, Homola $\mathrm{D}$, et al. Outgrowth of the bacterial airway microbiome after rhinovirus exacerbation of chronic obstructive pulmonary disease. Am J Respir Crit Care Med. 2013;188:1224-31. https://doi.org/10.1164/ rccm.201302-0341OC.

Morris DE, Cleary DW, Clarke SC. Secondary bacterial infections associated with influenza pandemics. Front Microbiol. 2017;8. https:// doi.org/10.3389/fmicb.2017.01041.

Morrow LE, Kollef MH, Casale TB. Probiotic prophylaxis of ventilatorassociated pneumonia: a blinded, randomized, controlled trial. Am J Respir Crit Care Med. 2010;182:1058-64. https://doi.org/10.1164/ rccm.200912-1853OC.

Nathan N, Prevost B, Corvol H. Atypical presentation of COVID-19 in young infants. Lancet. 2020;395:1481. https://doi.org/10.1016/ S0140-6736(20)30980-6.

Negi S, Pahari S, Bashir H, Agrewala JN. Gut microbiota regulates mincle mediated activation of lung dendritic cells to protect against Mycobacterium tuberculosis. Front Immunol. 2019;10:1142. https://doi.org/10.3389/fimmu.2019.01142.

Nguyen DT, Louwen R, Elberse K, van Amerongen G, Yüksel S, Luijendijk A, et al. Streptococcus pneumoniae enhances human respiratory syncytial virus infection in vitro and in vivo. PLoS One. 2015;10:e0127098. https://doi.org/10.1371/journal.pone. 0127098.

Perlot T, Penninger JM. ACE2 - from the renin-angiotensin system to gut microbiota and malnutrition. Microbes Infect. 2013;15:866-73. https://doi.org/10.1016/j.micinf.2013.08.003.

Prill MM, Iwane MK, Edwards KM, Williams JV, Weinberg GA, Staat MA, et al. Human Coronavirus in young children hospitalized for acute respiratory illness and asymptomatic controls. Pediatr Infect Dis J. 2012;31:235-40. https://doi.org/10.1097/INF. $0 \mathrm{~b} 013 \mathrm{e} 31823 \mathrm{e} 07 \mathrm{fe}$.

Reddinger RM, Luke-Marshall NR, Hakansson AP, Campagnari AA. Host physiologic changes induced by influenza A virus lead to Staphylococcus aureus biofilm dispersion and transition from asymptomatic colonization to invasive disease. MBio. 2016;7. https://doi.org/10.1128/mBio.01235-16.

Robles Alonso V, Guarner F. Linking the gut microbiota to human health. Br J Nutr. 2013;109(Suppl 2):S21-6. https://doi.org/10.1017/ S0007114512005235.

Seed PC. The human mycobiome. Cold Spring Harb Perspect Med. 2014;5:a019810. https://doi.org/10.1101/cshperspect.a019810.
Sharma S, Singh I, Haider S, Malik MZ, Ponnusamy K, Rai E. ACE2 Homo-dimerization, human genomic variants and interaction of host proteins explain high population specific differences in outcomes of COVID19. BioRxiv. 2020:2020.04.24.050534. https://doi.org/10. 1101/2020.04.24.050534.

Shastry RP, Rekha PD. Bacterial cross talk with gut microbiome and its implications: a short review. Folia Microbiol (Praha). 2020. https:// doi.org/10.1007/s12223-020-00821-5.

Shen K, Yang Y, Wang T, Zhao D, Jiang Y, Jin R, et al. Diagnosis, treatment, and prevention of 2019 novel coronavirus infection in children: experts' consensus statement. World J Pediatr. 2020;16: 223-31. https://doi.org/10.1007/s12519-020-00343-7.

Shi Y, Wang Y, Shao C, Huang J, Gan J, Huang X, et al. COVID-19 infection: the perspectives on immune responses. Cell Death Differ. 2020;27:1451-4. https://doi.org/10.1038/s41418-020-0530-3.

Shimizu K, Yamada T, Ogura H, Mohri T, Kiguchi T, Fujimi S, et al. Synbiotics modulate gut microbiota and reduce enteritis and ventilator-associated pneumonia in patients with sepsis: a randomized controlled trial. Crit Care. 2018;22:239. https://doi.org/10. 1186/s13054-018-2167-x.

Siordia JA. Epidemiology and clinical features of COVID-19: a review of current literature. J Clin Virol. 2020;127:104357. https://doi.org/10. 1016/j.jcv.2020.104357.

Sokolowska M, Frei R, Lunjani N, Akdis CA, O’Mahony L. Microbiome and asthma. Asthma Res Pract. 2018;4:1. https://doi.org/10.1186/ s40733-017-0037-y.

Sommer F, Bäckhed F. The gut microbiota - masters of host development and physiology. Nat Rev Microbiol. 2013;11:227-38. https:// doi.org/10.1038/nrmicro2974.

Sörensen M, Kantorek J, Byrnes L, Boutin S, Mall MA, Lasitschka F, et al. Pseudomonas aeruginosa modulates the antiviral response of bronchial epithelial cells. Front Immunol. 2020;11. https://doi.org/ 10.3389/fimmu.2020.00096.

Sudaryatma PE, Nakamura K, Mekata H, Sekiguchi S, Kubo M, Kobayashi I, et al. Bovine respiratory syncytial virus infection enhances Pasteurella multocida adherence on respiratory epithelial cells. Vet Microbiol. 2018;220:33-8. https://doi.org/10.1016/j. vetmic.2018.04.031.

Sze MA, Dimitriu PA, Hayashi S, Elliott WM, McDonough JE, Gosselink JV, et al. The lung tissue microbiome in chronic obstructive pulmonary disease. Am J Respir Crit Care Med. 2012;185: 1073-80. https://doi.org/10.1164/rccm.201111-2075OC.

Tan H-X, Esterbauer R, Vanderven HA, Juno JA, Kent SJ, Wheatley AK. Inducible bronchus-associated lymphoid tissues (iBALT) serve as sites of B cell selection and maturation following influenza infection in mice. Front Immunol. 2019;10. https://doi.org/10.3389/fimmu. 2019.00611.

Tay MZ, Poh CM, Rénia L, MacAry PA, Ng LFP. The trinity of COVID19: immunity, inflammation and intervention. Nat Rev Immunol. 2020;20:1-12. https://doi.org/10.1038/s41577-020-0311-8.

Thursby E, Juge N. Introduction to the human gut microbiota. Biochem J. 2017;474:1823-36. https://doi.org/10.1042/BCJ20160510.

Ubags NDJ, Marsland BJ. Mechanistic insight into the function of the microbiome in lung diseases. Eur Respir J. 2017;50:1602467. https://doi.org/10.1183/13993003.02467-2016.

Underhill DM, Iliev ID. The mycobiota: interactions between commensal fungi and the host immune system. Nat Rev Immunol. 2014;14: 405-16. https://doi.org/10.1038/nri3684.

Venkataraman A, Bassis CM, Beck JM, Young VB, Curtis JL, Huffnagle $\mathrm{GB}$, et al. Application of a neutral community model to assess structuring of the human lung microbiome. MBio. 2015;6. https://doi. org/10.1128/mBio.02284-14.

Vieira AT, Fukumori C, Ferreira CM. New insights into therapeutic strategies for gut microbiota modulation in inflammatory diseases. Clin Transl Immunol. 2016;5:e87. https://doi.org/10.1038/cti.2016.38. 
Wan Y, Shang J, Graham R, Baric RS, Li F. Receptor recognition by the Novel Coronavirus from Wuhan: an analysis based on decade-long structural studies of SARS Coronavirus. J Virol. 2020;94. https:// doi.org/10.1128/JVI.00127-20.

Wang H, Lian P, Niu X, Zhao L, Mu X, Feng B, et al. TLR4 deficiency reduces pulmonary resistance to Streptococcus pneumoniae in gut microbiota-disrupted mice. PLoS One. 2018;13:e0209183. https:// doi.org/10.1371/journal.pone.0209183.

Wang L, Wang Y, Ye D, Liu Q. A review of the 2019 Novel Coronavirus (COVID-19) based on current evidence. Int J Antimicrob Agents. 2020;55:105948. https://doi.org/10.1016/j.ijantimicag.2020. 105948 .

Wheeler ML, Limon JJ, Bar AS, Leal CA, Gargus M, Tang J, et al. Immunological consequences of intestinal fungal dysbiosis. Cell Host Microbe. 2016;19:865-73. https://doi.org/10.1016/j.chom. 2016.05.003.

WHO. Coronavirus disease (COVID-19) pandemic. https://www.who. int/emergencies/diseases/novel-coronavirus-2019. Date accessed: 21.10.2020.

Wilson BA, Ho M. Pasteurella multocida: from Zoonosis to cellular microbiology. Clin Microbiol Rev. 2013;26:631-55. https://doi.org/ 10.1128/CMR.00024-13.

Wu D, Wu T, Liu Q, Yang Z. The SARS-CoV-2 outbreak: what we know. Int J Infect Dis. 2020a;94:44-8. https://doi.org/10.1016/j. ijid.2020.03.004.

Wu F, Zhao S, Yu B, Chen Y-M, Wang W, Song Z-G, et al. A new coronavirus associated with human respiratory disease in China. Nature. 2020b;579:265-9. https://doi.org/10.1038/s41586-0202008-3.

Xia J, Tong J, Liu M, Shen Y, Guo D. Evaluation of coronavirus in tears and conjunctival secretions of patients with SARS-CoV-2 infection. J Med Virol. 2020;92:589-94. https://doi.org/10.1002/jmv.25725.

Yan R, Zhang Y, Li Y, Xia L, Guo Y, Zhou Q. Structural basis for the recognition of SARS-CoV-2 by full-length human ACE2. Science. 2020;367:1444-8. https://doi.org/10.1126/science.abb2762.

Ye Z-W, Yuan S, Yuen K-S, Fung S-Y, Chan C-P, Jin D-Y. Zoonotic origins of human coronaviruses. Int J Biol Sci. 2020;16:1686-97. https://doi.org/10.7150/ijbs.45472.

Yi H, Yong D, Lee K, Cho Y-J, Chun J. Profiling bacterial community in upper respiratory tracts. BMC Infect Dis. 2014;14:583. https://doi. org/10.1186/s12879-014-0583-3.

Yi Y, Lagniton PNP, Ye S, Li E, Xu R-H. COVID-19: what has been learned and to be learned about the novel coronavirus disease. Int J Biol Sci. 2020;16:1753-66. https://doi.org/10.7150/ijbs.45134.
Young RP, Hopkins RJ, Marsland B. The gut-liver-lung axis. Modulation of the innate immune response and its possible role in chronic obstructive pulmonary disease. Am J Respir Cell Mol Biol. 2016;54: 161-9. https://doi.org/10.1165/rcmb.2015-0250PS.

Yuen K-S, Ye Z-W, Fung S-Y, Chan C-P, Jin D-Y. SARS-CoV-2 and COVID-19: the most important research questions. Cell Biosci. 2020;10:40. https://doi.org/10.1186/s13578-020-00404-4.

Yuki K, Fujiogi M, Koutsogiannaki S. COVID-19 pathophysiology: a review. Clin Immunol Orlando Fla. 2020;215:108427. https://doi. org/10.1016/j.clim.2020.108427.

Zeng J, Wang C-T, Zhang F-S, Qi F, Wang S-F, Ma S, et al. Effect of probiotics on the incidence of ventilator-associated pneumonia in critically ill patients: a randomized controlled multicenter trial. Intensive Care Med. 2016;42:1018-28. https://doi.org/10.1007/ s00134-016-4303-x.

Zhang D, Li S, Wang N, Tan H-Y, Zhang Z, Feng Y. The cross-talk between gut microbiota and lungs in common lung diseases. Front Microbiol. 2020a;11:301. https://doi.org/10.3389/fmicb.2020. 00301.

Zhang H, Penninger JM, Li Y, Zhong N, Slutsky AS. Angiotensinconverting enzyme 2 (ACE2) as a SARS-CoV-2 receptor: molecular mechanisms and potential therapeutic target. Intensive Care Med. 2020b;46:1-5. https://doi.org/10.1007/s00134-020-05985-9.

Zhang J, Litvinova M, Wang W, Wang Y, Deng X, Chen X, et al. Evolving epidemiology and transmission dynamics of coronavirus disease 2019 outside Hubei province, China: a descriptive and modelling study. Lancet Infect Dis. 2020c;20:793-802. https://doi. org/10.1016/S1473-3099(20)30230-9.

Zheng J. SARS-CoV-2: an emerging Coronavirus that causes a global threat. Int J Biol Sci. 2020;16:1678-85. https://doi.org/10.7150/ijbs. 45053.

Zhou P, Yang X-L, Wang X-G, Hu B, Zhang L, Zhang W, et al. A pneumonia outbreak associated with a new coronavirus of probable bat origin. Nature. 2020;579:270-3. https://doi.org/10.1038/ s41586-020-2012-7.

Zhuang H, Cheng L, Wang Y, Zhang Y-K, Zhao M-F, Liang G-D, et al. Dysbiosis of the gut microbiome in lung cancer. Front Cell Infect Microbiol. 2019;9:112. https://doi.org/10.3389/fcimb.2019.00112.

Publisher's note Springer Nature remains neutral with regard to jurisdictional claims in published maps and institutional affiliations. 